\title{
Physician Perceptions of Catching COVID-19
}

\author{
P. Murali Doraiswamy, MBBS, FRCP ${ }^{1}$
}

Mohan Chilukuri, $\mathrm{MD}^{2}$

Dan Ariely, $\mathrm{PhD}^{3}$

Alexandra R. Linares, $\mathrm{BS}^{1}$

${ }^{1}$ Departments of Psychiatry and Medicine, Duke University School of Medicine

${ }^{2}$ Department of Family Medicine, University of North Carolina School of Medicine

${ }^{3}$ Center for Advanced Hindsight, Duke University

Corresponding author: P. Murali Doraiswamy, murali.doraiswamy@duke.edu, (919) 684-5929 


\begin{abstract}
Background: Risk perception, influenced and biased by multiple factors, can affect behavior.
\end{abstract}

Objective: To assess the variability of physician perceptions of catching COVID-19.

Design: Cross sectional, random stratified sample of physicians registered with Sermo, a global networking platform open to verified and licensed physicians.

Main outcome measures: The survey asked: "What is your likelihood of catching COVID-19 in the next three months?" The physicians were asked to give their best estimate as an exact percentage.

Results: The survey was completed by 1004 physicians (40 countries, 67 specialties, 49\% frontline [e.g. ER, infectious disease, internal medicine]) with a mean (SD) age of 49.14 (12) years. Mean (SD) self-risk estimate was $32.3 \% \pm 26 \%$ with a range from $0 \%$ to $100 \%$ (Figure 1a). Risk estimates were higher in younger ( $<50$ years) doctors and in non-US doctors versus their older and US counterparts $(\mathrm{p}<0.05$ for all) (Figure 1b). Risk estimates were higher among front line versus non-frontline doctors $(\mathrm{p}<0.05)$. Risk estimates were higher for women than men $(\mathrm{p}<0.05)$ among respondents $(60 \%)$ reporting gender.

Conclusions: To our knowledge, this is the first global study to document physician risk perceptions for catching COVID-19 and how it is impacted by age, gender, practice specialty and geography. Accurate calibration of risk perception is vital since both over- and underestimation of risk could impact physician behavior and have implications for public health. 
medRxiv preprint doi: https://doi.org/10.1101/2021.01.15.20249089; this version posted January 24, 2021. The copyright holder for this preprint (which was not certified by peer review) is the author/funder, who has granted medRxiv a license to display the preprint in perpetuity.

\section{Introduction}

Despite more than 87 million cases of COVID-19 worldwide, the number of infected physicians is not fully known. While efforts are underway to chart the actual infection risk among physicians (1-7), it is equally important to understand perceived risk which influences behavior. Risk perception is a subjective process in which people use heuristics (shortcuts) to evaluate information (8). Such heuristics are influenced by many factors including personal experiences and beliefs - one reason why people see the same risk differently. This process is subject to cognitive biases - for example, people often overestimate risks that are beyond their control and underestimate risks that they undertake willingly $(8,9)$.

\section{Methods}

This is an analysis of an anonymous, cross-sectional, random, stratified, IRB exempt survey, done September 9-15, 2020, of verified physicians registered with Sermo, a digital platform for medical crowdsourcing. Following online informed consent, this survey aimed to sample 1,000 doctors equally divided between USA, EU and rest of the world (RoW) on many topics of which one question pertained to perceived risk. The self-risk question was "What is your likelihood of catching COVID-19 in the next three months?" The physicians were asked to give their best estimate as an exact percentage. Data were analyzed with JMP Pro15 and Protobi.

\section{Results}

The survey was completed by 1004 physicians (40 countries, 67 specialties, 49\% frontline [e.g. ER, infectious disease, internal medicine]) with a mean (SD) age of 49.14 (12) years. Mean (SD) self-risk estimate was $32.3 \%+26 \%$ with a range from $0 \%$ to $100 \%$ (Figure 1a). Risk estimates were higher in younger ( $<50$ years) doctors and in non-US doctors versus their older 
medRxiv preprint doi: https://doi.org/10.1101/2021.01.15.20249089; this version posted January 24, 2021. The copyright holder for this preprint (which was not certified by peer review) is the author/funder, who has granted medRxiv a license to display the preprint in perpetuity.

All rights reserved. No reuse allowed without permission.

and US counterparts ( $\mathrm{p}<0.05$ for all) (Figure $1 \mathrm{~b}$ ). Risk estimates were higher among front line versus non-frontline doctors $(\mathrm{p}<0.05)$. Risk estimates were higher for women than $\mathrm{men}(\mathrm{p}<0.05)$ among respondents $(60 \%)$ reporting gender.

Figure 1A. Distribution of risk prediction for overall sample $(\mathrm{N}=1004)$. Upper panel is a line box whisker and bottom panel shows the frequency distribution.

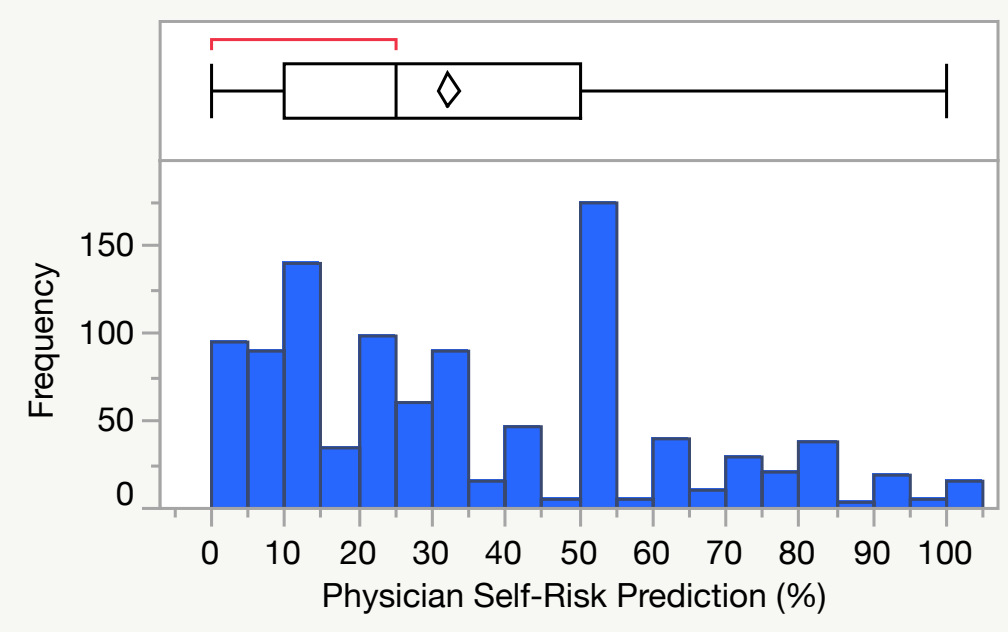

Figure1B. Mean (SD) risk estimates by age, frontline status, and geographic region.

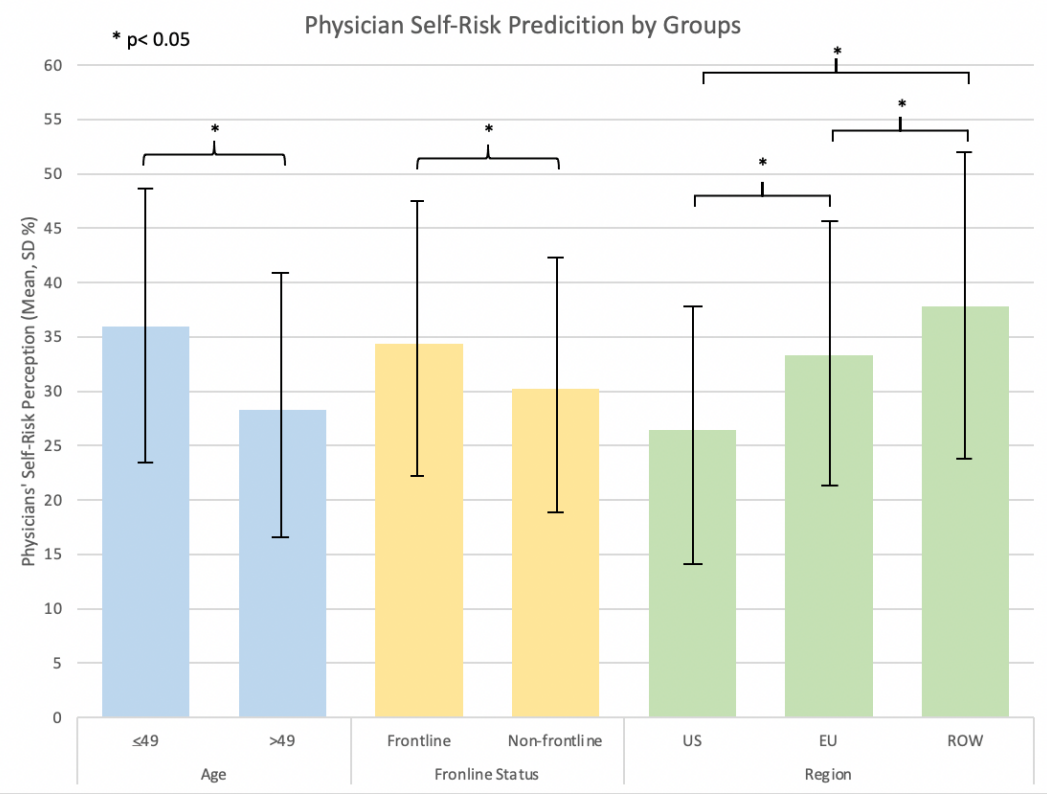


medRxiv preprint doi: https://doi.org/10.1101/2021.01.15.20249089; this version posted January 24, 2021. The copyright holder for this preprint (which was not certified by peer review) is the author/funder, who has granted medRxiv a license to display the preprint in perpetuity.

All rights reserved. No reuse allowed without permission.

\section{Discussion}

The average 3-month risk perception estimate of $32 \%$, if true, would mean that one-third of all physicians worldwide (including some 258,000 doctors in the US) will be infected by December 2020. This is higher than the reported physician SARS-CoV-2 seroprevalence rates of 3.6-19\% (1-7). This survey also finds a high variability of risk perception and differences by age, gender and geography - suggesting factors other than actual risk may be contributing.

Measuring and calibrating risk perception correctly is important since there are consequences to both overestimation and underestimation $(8,9)$. Overestimation of risk can lead to greater compliance with safety regulations but also anxiety and avoidance of necessary activities (e.g., routine physical exams). Underestimation can raise a physician's risk for catching COVID-19 and/or becoming super-spreaders. Physician risk perceptions may also influence how they educate patients and formulate public health safety policies. Lastly, this survey provides insights into how the broader health worker community may perceive infection risk.

Despite limitations such as cross-sectional nature, single question, and inability to control for all possible confounders, this survey provides foundational insights into physicians' risk perception for COVID-19. Prospective studies of both actual and perceived risk across different medical specialties may enhance occupational safety.

\section{Ethics Declaration}

This anonymous survey was conducted in September 2020 following an online informed consent process. This was a broad survey across many topics of which one question pertained to immunology. De-identified data was analyzed for this report. This was reviewed and deemed exempt research by the Duke University Medical Center Institutional Review Board. 
medRxiv preprint doi: https://doi.org/10.1101/2021.01.15.20249089; this version posted January 24, 2021. The copyright holder for this preprint (which was not certified by peer review) is the author/funder, who has granted medRxiv a license to display the preprint in perpetuity.

All rights reserved. No reuse allowed without permission.

\section{Funding Statement}

The authors received no external funding support for these analyses and have no financial ties to Sermo. Sermo provided the platform but was not involved in data interpretation, manuscript preparation, or decision to submit. Authors had full access to all the data and accept responsibility to submit for publication.

\section{Acknowledgements}

The authors thank Sermo and the physicians who took part in the survey.

\section{References}

1. CDC COVID Data Tracker [Internet]. Centers for Disease Control and Prevention. 2020. Cases \& Deaths among Healthcare Personnel; [cited 2020 Dec 16]; [about 1 screen]. Available from: https://covid.cdc.gov/covid-datatracker $/$ ?CDC_AA_refVal=https $\% 3 \mathrm{~A} \% 2 \mathrm{~F} \% 2 \mathrm{Fwww} . \mathrm{cdc} . \mathrm{gov} \% 2 \mathrm{Fcoronavirus} \% 2 \mathrm{~F} 2019$ ncov\%2Fcases-updates $\% 2$ Fcases-in-us.html\#health-care-personnel

2. Self WH, Tenforde MW, Stubblefield WB, Feldstein LR, Steingrub JS, Shapiro NI, et al. Seroprevalence of SARS-CoV-2 among frontline health care personnel in a multistate hospital network-13 academic medical centers, April-June 2020. Morbidity and Mortality Weekly Report. 2020;69(35):1221-6.

3. Martin CA, Patel P, Goss C, Jenkins DR, Price A, Barton L, et al. Demographic and occupational determinants of anti-SARS-CoV-2 IgG seropositivity in hospital staff. Journal of Public Health. 2020. 
medRxiv preprint doi: https://doi.org/10.1101/2021.01.15.20249089; this version posted January 24, 2021. The copyright holder for this preprint

(which was not certified by peer review) is the author/funder, who has granted medRxiv a license to display the preprint in perpetuity.

All rights reserved. No reuse allowed without permission.

4. Madsen T, Levin N, Niehus K, Law K, Mayer J, Chapman M, et al. Prevalence of IgG antibodies to SARS-CoV-2 among emergency department employees. The American Journal of Emergency Medicine. 2020:S0735-6757(20)30306-5.

5. Iversen K, Bundgaard H, Hasselbalch RB, Kristensen JH, Nielsen PB, Pries-Heje M, et al. Risk of COVID-19 in health-care workers in Denmark: an observational cohort study. The Lancet Infectious Diseases. 2020;20(12):1401-8.

6. Goenka MK, Afzalpurkar S, Goenka U, Das SS, Mukherjee M, Jajodia S, et al. Seroprevalence of COVID-19 Amongst Health Care Workers in a Tertiary Care Hospital of a Metropolitan City from India. The Lancet Regional Health - Western Pacific. 2020;3.

7. Nguyen LH, Drew DA, Graham MS, Joshi AD, Guo C-G, Ma W, et al. Risk of COVID19 among front-line health-care workers and the general community: a prospective cohort study. The Lancet Public Health. 2020;5(9):e475-e83.

8. Ariely D. Predictably Irrational, Revised and Expanded Edition. New York, NY: HarperCollins Publishers; 2009.

9. Schneier B. Beyond Fear: Thinking Sensibly about Security in an Uncertain World. New York, NY: Copernicus Books; 2003. 